\title{
Effect of Azoxystrobin 8.3\%w/w + Mancozeb 68.75\% on Powdery and Downy mildew Pathogens under In vitro condition
}

\author{
${ }^{1}$ Pannerselvam Ahila devi, Karikalan Vinothini ${ }^{1}$ and ${ }^{1}$ Velapagounder Prakasam \\ Department of Plant Pathology, Centre for Plant Protection StudiesTamil Nadu Agricultural University, \\ Coimbatore - 625104
}

\begin{abstract}
Field surveys were conducted in 3 major grapevine growing districts in Tamil Nadu viz., Coimbatore, Theni and Dindugal. The downy mildew infection on leaves was the highest (PDI 76.92 in Cumbum of Theni district. In the survey on the incidence of powdery mildew showed that the highest incidence of PDI on leaves, inflorescence and fruits in Cumbum of Theni with records of 65.49, 63.56, 61.23 percent. The pathogenecity test revealed that the downy mildew isolate D-TCl of Theni district was found to be more virulent with highest PDI of (42.35). The powdery mildew isolate of Cumbum (P-TC1) of Theni district was found to be more virulent by recording the maximum PDI of (36.94). Among the different fungicide tested against spore germination of P.viticola, Azoxystrobin 8.3\%w/w + Mancozeb 68.75 at 0.36 per cent recorded $89.26 \%$ inhibition. The fungicide Azoxystrobin 8.3\% + Mancozeb 68.75 in all three concentrations, was found to be superior in inhibiting the spore germination of $U$. necator by recording $90.27 \%, 89.91 \%, 80.70 \%$ respectively in $0.36,0.30$ and $0.24 \%$ concentrations.
\end{abstract}

Key words: Grapevine - pathogenecity-Spore germination - Azoxystrobin - Mancozeb

\section{Introduction}

Grapevine (Vitis vinifera L.) is an important commercial fruit crop and one of the most widely cultivated crop in temperate, sub-tropical and tropical regions of the world. There are over 8,000 grape varieties in worldwide and grape appears in the top ten of the world's favourite fruits, along with tomatoes, mangos and bananas. Grapevine cultivation offers a great economic potential due to its higher yield and monetary returns owing to the export to Gulf, European countries and to some extent West Asian countries. Grape is basically a sub- tropical crop. However, in India, grapes are cultivated for their excellence also under tropical conditions. In world they are cultivated in an area of $7.2 \mathrm{~m}$ ha with a total production of $67.32 \mathrm{~m}$ tonnes during 2011. In India, grapevine is grown in an area of 111 thousand ha.India is the $12^{\text {th }}$ largest grape producing country in the world with the production of 1235.00 thousand tonnes.(Indian Horticulture Database -2011[1]). Production of grapevines is threatened by biotic (viruses, bacteria, fungi and insects) and abiotic stresses (i.e. drought, winter cold). From these stresses fungal infections reduce mostly the yield and damage fruit and wine quality. Fungal diseases viz., downy mildew Plasmopara viticola, Powdery mildew Uncinula necator and Anthracnose Elsinoe ampelina are found to be the major constraints in grapevine cultivation.

Among the fungal diseases, downy mildew caused by $P$. viticola is the most destructive and explosive disease of grapevine. It has been recorded in 91 countries from temperate to tropical zones (CMI, 1988[2]). Powdery mildew caused by $U$. necator is an another important endemic fungal diseases on commercial grapevine varieties and it is not possible to harvest good quality fruits without prophylactic measures (Rao, 1991[3]). Recently several fungicides viz,, propicanozole, fenarimol, bupirimate, penconozole, dimethomorph, triademeton, pyrazophos, hexaconazole, chlorothalonil and flusilazole were introduced in India for control of powdery mildew pathogens. In addition, several new molecules are also tested against downy mildew pathogens, most important ones are metalxyl and Fosetyl- Al group of fungicides. Ravikumar (2007[4]) reported that the application of Ridomil Gold 68 WG (metalaxyl M + mancozeb4+64WG) @ 0.25 per cent reduced the incidence of downy mildew in grapevine up to 71 per cent. But there are certain strains of Oomycetous fungi, which are resistant to metalaxyl. So new fungicide molecule with novel mode of action is needed to replace the failing compounds.

Azoxystrobin is a systemic fungicide. It is absorbed through the roots and translocated in the xylem to the stems and leaves, or through leaf surfaces to the leaf tips and growing edges. Bartlett $e t$ al., 2001[5] reported that the huge impact of the strobilurins on agriculture is well exemplified by the development of azoxystrobin which has now been registered for use on a broad spectrum of fungal diseases on 84 different crops in 71 countries, representing over 400 crop/disease systems

Mancozeb is a coordination product of Zinc ion and Manganese ethylene bis-dithio-carbamate. This compound has a negligible vapour pressure, therefore it has a low potential to volatilize into the air. In water, mancozeb can be quickly hydrolyzed with a half-life of less than 2 days Mancozeb is used to protect many fruit, vegetable, nut and field crops against a wide spectrum of diseases, including potato blight, leaf spot, scab (on apples 
and pears) and rust (on roses). It is also used for seed treatment of cotton, potatoes, corn, safflower, sorghum, peanuts, tomatoes, flax and cereal grains Berg (1988).[6]

In the quest for find newer and more efficacious molecules, the present investigation was carried out using a new formulation. A combination of Azoxystrobin $8.3 \%$ w/w + Mancozeb $64.75 \mathrm{w} / \mathrm{w}$ ) of United Phosphorus Limited, Mumbai

The efficacy of the combined action may be much higher against the fungal pathogens with no risk of development of resistance against fungicides. With this background, the present study was carried out envisaging the Survey for the incidence of downy mildew and powdery mildew diseases of Grapevine in Tamil Nadu and to study the efficacy of Azoxystrobin 8.3\% + Mancozeb 64.7 against powdery and downy mildew pathogens.

\section{Materials and methods}

1. Survey for the incidence of downy mildew and powdery mildew in Tamil Nadu

An intensive survey was conducted during 2011 in some of the grapevine growing districts of Tamil Nadu viz., Coimbatore, Dindugal and Theni to assess the severity of the disease incidence of downy mildew and powdery mildew and per cent disease index was calculated as per the standard grade chart given by Jamdar and Desai (1997)[7]

\subsection{Raising of grapevine plants}

The variety Muscat, which is found to be susceptible to both downy mildew and powdery mildew was used for all studies in this investigation.

The grapevine variety Muscat was raised in pots by vegetative propagation under glass house conditions. The cuttings were collected from mature canes of healthy and virus - free vines. Depending upon the length of internodes in a cultivar, mature wood was cut into pieces of about $25-30 \mathrm{~cm}$ long which contained atleast four buds. The thickness of cuttings was $7-8 \mathrm{~mm}$ dia (pencil thickness). The lower end of the cuttings was soaked in $50 \mathrm{ppm}$ of Rootex (Indole Butyric Acid) for $24 \mathrm{~h}$. Then the cuttings were planted in mud pots containing red soil, sand and farmyard manure at 3:1:1 ratio. The pots were watered periodically.

\subsection{Collection and maintenance of inoculum of Plasmopara viticola and Uncinula necator in glass house}

Grapevine leaves showing typical downy mildew and powdery mildew symptoms were collected from different districts of Tamil Nadu. In the case of downy mildew sporangial suspension was prepared by harvesting the diseased leaves and flooding the leaves with sterile distilled water. The process was repeated three times to obtain sufficient inoculum. In the case of U.necator conidial suspension was prepared as described above. The sporangial and conidial suspension was strained separately through two layers of cheese cloth and centrifuged twice at $4000 \mathrm{rpm}$ for $30 \mathrm{~min}$. The sporangial and conidial concentrations were adjusted to $5 \times 10^{6}$ per $\mathrm{ml}$ with sterile distilled water and used for maintaining the downy mildew and powdery mildew inoculum in glass house. To maintain the sufficient inoculum, grape vine plants in the glass house were sprayed with spore suspension, after making slight pin pricks. They were then covered with polythene bag for $24 \mathrm{~h}$ to maintain high humidity for disease development (Vimala, 2005)[8] The different isolates of downy mildew fungus was maintained for further studies.

\subsection{Pathogenicity of P.viticola and $\boldsymbol{U}$.necator in grapevine leaves}

Sporangial suspension of downy mildew and conidial suspension of powdery mildew was prepared by scrapping the sporangia and conidia from the infected leaves of grapes. The sporangial and conidial suspension concentration was adjusted to $5 \times 10^{6}$ per $\mathrm{ml}$ using a haemocytometer. These suspensions were sprayed separately on healthy leaves of grapevine in the Plant Pathology glass house. The plants were covered by polythene bag for 24 hours to maintain high humidity for disease development. The development of the disease was observed after 10 days of inoculation and PDI was worked out to identify the best isolate for further study.

\subsection{Evaluation of different fungicides}

A new formulation of Azoxystrobin 8.3\%w/w + Mancozeb $68.75 \%$ w/w of United Phosphorous Limited, Mumbai was used for all the studies.

\subsubsection{Efficacy of Azoxystrobin 8.3\%w/w + Mancozeb 68.75\% and other fungicides against sporangial germination of P.viticola}

In order to compare the efficacy of Azoxystrobin 8.3\%w/w + Mancozeb 68.75\% and other fungicides for the control of downy mildew of grapevine, preliminary screening of the fungicides was made. Leaves showing downy mildew growth were tapped at 5 AM to dislodge the preformed sporangia and were collected in a petri dish containing sterile water. A drop of fungicides UPF 509 at different concentration $0.24 \%, 0.3 \%, 0.36 \%$ and other fungicides 
Mancozeb at $0.4 \%$, Azoxystrobin at $0.1 \%$, Hexaconazole at $0.6 \%$ and Metalaxyl+ Mancozeb at $0.5 \%$ was placed individually in a cavity slide and allowed to air dry and then a drop of the sporangial suspension $\left(5 \times 10^{6}\right.$ sporangia/ $\left.\mathrm{ml}\right)$ was added and incubated at $20^{\circ} \mathrm{C}$ for six hours in moist Petri dishes under darkness. The sporangial suspension in sterile water served as control. The treatments were replicated thrice. Observations on the sporangial germination were recorded after six hours of incubation by counting the total number of sporangia and number of sporangia germinated in each microscopic field. Three such microscopic fields were observed and the mean per cent sporangial germination and per cent inhibition of sporangial germination were worked out (CSFT, 1943).[9]

\subsubsection{Efficacy of Azoxystrobin 8.3\%w/w + Mancozeb 68.75\% and other fungicides against conidial germination of $U$. necator}

The efficacy of Azoxystrobin 8.3\%w/w + Mancozeb 68.75\% and other fungicide against the conidial germination of U. necator was assessed by Detached leaf technique (Varalakshmi et al., 1999)[10]. Grapevine leaves were washed in sterile distilled water and air dried. Fungicide UPF 509 at different concentration $0.24 \%$, $0.3 \%, 0.36 \%$ and other fungicides Mancozeb at $0.4 \%$, Azoxystrobin at $0.1 \%$, Hexaconazole at $0.6 \%$ and Metalaxyl+ Mancozeb at $0.5 \%$ were placed individually on the adaxial surface of the leaf and the droplets were evenly spread with a fine camel hairbrush and allowed to air dry. The treated leaves were inoculated with the conidia of U. necator $\left(5 \times 10^{6}\right.$ conidia/ $\left.\mathrm{ml}\right)$. The leaves sprayed with the conidial suspension alone served as control. Three leaves from each treatment were transferred to a Petri dish with their petioles dipped in water and incubated at $20^{\circ} \mathrm{C}$. After $72 \mathrm{~h}$, the leaves were observed under the microscope (equipped with fine light arrangement) for conidial germination. The total and germinated conidia were counted in three microscopic fields and per cent inhibition of conidial germination was calculated.

\subsection{Statistical analysis}

The data generated from various experiments of this study were statistically analyzed by DMRT with IRRISTAT software. The data with per cent values were subjected to arc sine transformation

Table: 1. Survey for the incidence of downy mildew and powdery mildew in major grapevine growing areas of Tamil Nadu

\begin{tabular}{|c|c|c|c|c|c|c|c|}
\hline \multirow{3}{*}{$\begin{array}{c}\text { Name of the } \\
\text { district }\end{array}$} & \multirow{3}{*}{ Name of the village } & \multirow{2}{*}{\multicolumn{3}{|c|}{$\begin{array}{c}\text { Downy mildew } \\
\text { Percent disease Index* }\end{array}$}} & \multirow{2}{*}{\multicolumn{3}{|c|}{$\begin{array}{c}\text { Powdery mildew } \\
\text { Percent disease Index* }\end{array}$}} \\
\hline & & & & & & & \\
\hline & & Leaves & Infloroscence & Fruits & Leaves & Infloroscence & Fruits \\
\hline Coimbatore & Mathampatty & $\begin{array}{l}71.13^{\mathrm{b}} \\
(57.48)\end{array}$ & $\begin{array}{l}69.94^{\mathrm{b}} \\
(56.73)\end{array}$ & $\begin{array}{l}67.81^{\mathrm{b}} \\
(55.43)\end{array}$ & $\begin{array}{l}60.91^{\mathrm{bc}} \\
(51.30)\end{array}$ & $\begin{array}{l}59.34^{\mathrm{b}} \\
(50.36)\end{array}$ & $\begin{array}{l}57.34^{\mathrm{b}} \\
(49.20)\end{array}$ \\
\hline Coimbatore & Theeethipalayam & $\begin{array}{l}65.14^{\mathrm{d}} \\
(53.79) \\
\end{array}$ & $\begin{array}{l}61.21^{d} \\
(51.47)\end{array}$ & $\begin{array}{c}59.18^{\mathrm{d}} \\
(50.24) \\
\end{array}$ & $\begin{array}{l}54.95^{\mathrm{e}} \\
(47.81) \\
\end{array}$ & $\begin{array}{l}53.28^{d} \\
(46.83) \\
\end{array}$ & $\begin{array}{r}50.18^{\mathrm{d}} \\
(45.06) \\
\end{array}$ \\
\hline Coimbatore & Theenampalayam & $\begin{array}{c}73.26^{\mathrm{b}} \\
(58.82)\end{array}$ & $\begin{array}{c}70.32^{\mathrm{b}} \\
(56.98) \\
\end{array}$ & $\begin{array}{c}68.15^{\mathrm{b}} \\
(55.61)\end{array}$ & $\begin{array}{c}61.56^{\mathrm{b}} \\
(51.65)\end{array}$ & $\begin{array}{c}60.02^{\mathrm{b}} \\
(50.77)\end{array}$ & $\begin{array}{l}57.49^{\mathrm{b}} \\
(49.26) \\
\end{array}$ \\
\hline Coimbatore & Thondamuthur & $\begin{array}{l}70.62^{\mathrm{c}} \\
(57.17)\end{array}$ & $\begin{array}{l}69.49^{b} \\
(56.42)\end{array}$ & $\begin{array}{l}67.24^{b} \\
(55.06) \\
\end{array}$ & $\begin{array}{l}60.38^{\mathrm{c}} \\
(50.94)\end{array}$ & $\begin{array}{l}58.19^{\mathrm{bc}} \\
(49.66)\end{array}$ & $\begin{array}{l}56.14^{\mathrm{bc}} \\
(48.50)\end{array}$ \\
\hline Theni & Cumbum & $\begin{array}{r}76.92^{\mathrm{a}} \\
(61.27) \\
\end{array}$ & $\begin{array}{l}75.15^{\mathrm{a}} \\
(60.07) \\
\end{array}$ & $\begin{array}{r}72.32^{\mathrm{a}} \\
(58.24) \\
\end{array}$ & $\begin{array}{r}65.49^{\mathrm{a}} \\
(53.97) \\
\end{array}$ & $\begin{array}{r}63.56^{\mathrm{a}} \\
(52.83) \\
\end{array}$ & $\begin{array}{r}61.23^{\mathrm{a}} \\
(51.47) \\
\end{array}$ \\
\hline Theni & Odapatty & $\begin{array}{r}75.63^{a} \\
(60.40) \\
\end{array}$ & $\begin{array}{l}73.29^{\mathrm{a}} \\
(58.82) \\
\end{array}$ & $\begin{array}{r}71.69^{\mathrm{a}} \\
(57.80) \\
\end{array}$ & $\begin{array}{l}62.38^{\mathrm{b}} \\
(52.12) \\
\end{array}$ & $\begin{array}{c}60.12^{\mathrm{b}} \\
(50.83) \\
\end{array}$ & $\begin{array}{l}58.34^{\mathrm{b}} \\
(49.78) \\
\end{array}$ \\
\hline Theni & Surulipatty & $\begin{array}{l}69.72^{\mathrm{c}} \\
(56.60)\end{array}$ & $\begin{array}{l}66.53^{\mathrm{c}} \\
(54.63)\end{array}$ & $\begin{array}{l}64.63^{\mathrm{c}} \\
(53.49)\end{array}$ & $\begin{array}{l}58.94^{\mathrm{d}} \\
(50.13)\end{array}$ & $\begin{array}{l}58.04^{\mathrm{c}} \\
(49.60)\end{array}$ & $\begin{array}{r}54.82^{\mathrm{c}} \\
(47.75) \\
\end{array}$ \\
\hline Dindugal & Uthupatty & $\begin{array}{l}40.19^{f} \\
(39.29)\end{array}$ & $\begin{array}{l}35.24^{\mathrm{f}} \\
(36.39)\end{array}$ & $\begin{array}{l}32.47^{f} \\
(34.70)\end{array}$ & $\begin{array}{l}38.65^{g} \\
(38.41)\end{array}$ & $\begin{array}{l}37.21^{f} \\
(37.58)\end{array}$ & $\begin{array}{l}36.64^{\mathrm{e}} \\
(37.23) \\
\end{array}$ \\
\hline Dindugal & Chakkainayakanur & $\begin{array}{c}68.21^{\mathrm{c}} \\
(55.67)\end{array}$ & $\begin{array}{l}62.53^{d} \\
(52.24)\end{array}$ & $\begin{array}{c}60.78^{d} \\
(51.18)\end{array}$ & $\begin{array}{l}57.24^{\mathrm{d}} \\
(49.14)\end{array}$ & $\begin{array}{l}57.09^{c} \\
(49.02)\end{array}$ & $\begin{array}{l}53.24^{\mathrm{c}} \\
(46.83) \\
\end{array}$ \\
\hline Dindugal & Chinnalapatty & $\begin{array}{l}45.71^{\mathrm{e}} \\
(42.53)\end{array}$ & $\begin{array}{l}40.92^{\mathrm{e}} \\
(39.76) \\
\end{array}$ & $\begin{array}{l}38.24^{\mathrm{e}} \\
(38.17) \\
\end{array}$ & $\begin{array}{l}51.18^{f} \\
(45.63)\end{array}$ & $\begin{array}{l}49.68^{\mathrm{e}} \\
(44.77) \\
\end{array}$ & $\begin{array}{l}49.35^{\mathrm{d}} \\
(44.60)\end{array}$ \\
\hline
\end{tabular}

*Mean of three replications

Values in parentheses are arcsine-transformed values

In a column, means followed by a common letter are not significantly different at the 5\% level by DMRT 
Effect of Azoxystrobin 8.3\%w/w + Mancozeb 68.75\% on Powdery and Downy mildew Pathogens under

Table: 2. Pathogenicity tests with different isolates of P.viticola and U.necator under glass house condition

\begin{tabular}{|c|c|c|c|c|c|}
\hline \multirow[t]{2}{*}{ Name of district } & \multirow[t]{2}{*}{ Name of village } & \multicolumn{2}{|c|}{ Downy mildew } & \multicolumn{2}{|c|}{ Powdery mildew } \\
\hline & & Isolate & PDI on leaves* & Isolates & PDI on leaves* \\
\hline Coimbatore & Mathampatty & D-CM1 & $\begin{array}{c}31.15^{\mathrm{c}} \\
(33.89)\end{array}$ & P-CM1 & $\begin{array}{c}28.54^{\mathrm{c}} \\
(32.27)\end{array}$ \\
\hline Coimbatore & Theeethipalayam & D-CT2 & $\begin{array}{c}19.29^{f} \\
(25.99)\end{array}$ & P-CT2 & $\begin{array}{c}15.48^{g} \\
(23.11)\end{array}$ \\
\hline Coimbatore & Theenampalayam & D-CT3 & $\begin{array}{c}35.21^{\mathrm{b}} \\
(36.39)\end{array}$ & P-CT3 & $\begin{array}{c}31.46^{\mathrm{b}} \\
(34.08)\end{array}$ \\
\hline Coimbatore & Thondamuthur & D-CT4 & $\begin{array}{c}26.56^{\mathrm{d}} \\
(30.98)\end{array}$ & P-CT4 & $\begin{array}{l}25.28^{d} \\
(30.13)\end{array}$ \\
\hline Theni & Cumbum & D-TC1 & $\begin{array}{l}42.35^{\mathrm{a}} \\
(40.57)\end{array}$ & P-TC1 & $\begin{array}{c}36.94^{\mathrm{a}} \\
(37.41)\end{array}$ \\
\hline Theni & Odapatty & D-TO2 & $\begin{array}{c}40.16^{a} \\
(39.29)\end{array}$ & P-TO2 & $\begin{array}{c}34.28^{\mathrm{a}} \\
(35.79)\end{array}$ \\
\hline Theni & Surulipatty & D-TS3 & $\begin{array}{l}25.28^{d} \\
(30.13)\end{array}$ & P-TS3 & $\begin{array}{l}22.91^{\mathrm{e}} \\
(28.59)\end{array}$ \\
\hline Dindugal & Uthupatty & D-DU1 & $\begin{array}{c}14.94^{\mathrm{g}} \\
(22.71)\end{array}$ & P-DU1 & $\begin{array}{c}10.54^{\mathrm{h}} \\
(18.91)\end{array}$ \\
\hline Dindugal & Chakkainayakanur & D-DC2 & $\begin{array}{c}22.18^{\mathrm{e}} \\
(28.04)\end{array}$ & P-DC2 & $\begin{array}{c}19.45^{\mathrm{f}} \\
(26.13)\end{array}$ \\
\hline Dindugal & Chinnalapatty & D-DC3 & $\begin{array}{l}16.54^{\mathrm{g}} \\
(23.97)\end{array}$ & P-DC3 & $\begin{array}{c}12.86^{\mathrm{h}} \\
(20.96)\end{array}$ \\
\hline
\end{tabular}

* Mean of three replications

Values in parentheses are arcsine-transformed values

In a column, means followed by a common letter are not significantly different at the 5\% level by DMRT

Table 3. Efficacy of Azoxystrobin 8.3\%w/w + Mancozeb 68.75\% and other fungicides against spore germination of Plasmopara viticola and Uncinula necator

\begin{tabular}{|c|c|c|c|c|}
\hline \multirow[b]{2}{*}{ Treatment } & \multicolumn{2}{|c|}{ P.viticola } & \multicolumn{2}{|c|}{ U.necator } \\
\hline & $\begin{array}{c}\text { Percent } \\
\text { germination* }\end{array}$ & $\begin{array}{c}\text { Percent reduction over } \\
\text { Control }\end{array}$ & $\begin{array}{c}\text { Percent } \\
\text { germination* }\end{array}$ & $\begin{array}{l}\text { Percent reduction over } \\
\text { control }\end{array}$ \\
\hline $\begin{array}{l}\text { Azoxystrobin } 8.3 \%+\text { Mancozeb } \\
68.75 \%(99.6+800) \mathrm{g}_{\text {ai ha }}^{-1}(0.24 \%)\end{array}$ & $\begin{array}{l}21.31^{\mathrm{b}} \\
(27.48)\end{array}$ & 77.39 & $\begin{array}{l}18.34^{\mathrm{b}} \\
(25.35)\end{array}$ & 80.70 \\
\hline $\begin{array}{l}\text { Azoxystrobin } 8.3 \%+\text { Mancozeb } \\
68.75 \%(124.5+1000) \mathrm{g}^{\text {ai }} \mathrm{ha}^{-1} \\
(0.30 \%)\end{array}$ & $\begin{array}{l}10.46^{\mathrm{a}} \\
(18.86)\end{array}$ & 88.90 & $\begin{array}{l}9.58^{\mathrm{a}} \\
(18.02)\end{array}$ & 89.91 \\
\hline $\begin{array}{l}\text { Azoxystrobin } 8.3 \%+\text { Mancozeb } \\
68.75 \%(149.4+1200) \mathrm{g} \mathrm{ai} \mathrm{ha}^{-1} \\
(0.36 \%)\end{array}$ & $\begin{array}{l}10.12^{\mathrm{a}} \\
(18.54)\end{array}$ & 89.26 & $\begin{array}{c}9.24^{\mathrm{a}} \\
(17.69)\end{array}$ & 90.27 \\
\hline $\begin{array}{l}\text { Mancozeb } 75 \% \text { WP } 1500 \mathrm{~g}^{2} \mathrm{ha}^{-1} \\
(0.40 \%)\end{array}$ & $\begin{array}{l}35.31^{\mathrm{de}} \\
(36.45)\end{array}$ & 62.54 & $\begin{array}{l}22.52^{\mathrm{bc}} \\
(28.32)\end{array}$ & 76.30 \\
\hline $\begin{array}{l}\text { Azoxystrobin } 23 \% \text { SC } 125 \mathrm{~g} \text { ai ha } \\
(0.10 \%)\end{array}$ & $\begin{array}{l}26.34^{\mathrm{bc}} \\
(30.87)\end{array}$ & 72.06 & $\begin{array}{l}27.61^{\text {cd }} \\
(31.69)\end{array}$ & 70.94 \\
\hline $\begin{array}{l}\text { Hexaconazole } 2 \% \text { SC } 60 \mathrm{~g}_{\text {ai }} \mathrm{ha}^{-1} \\
(0.60 \%)\end{array}$ & $\begin{array}{l}42.12^{\mathrm{e}} \\
(40.46)\end{array}$ & 55.32 & $\begin{array}{l}39.21^{\mathrm{e}} \\
(38.76)\end{array}$ & 58.73 \\
\hline $\begin{array}{l}\text { Metalaxyl } 8 \%+\text { Mancozeb 64\% WP } \\
2000 \text { g ai } \text { ha }^{-1}(0.50 \%)\end{array}$ & $\begin{array}{l}31.25^{\mathrm{cd}} \\
(33.98)\end{array}$ & 66.85 & $\begin{array}{l}32.42^{\mathrm{de}} \\
(34.70)\end{array}$ & 65.88 \\
\hline Control & $\begin{array}{l}94.28^{f} \\
(77.18)\end{array}$ & - & $\begin{array}{l}95.03^{f} \\
(78.75)\end{array}$ & - \\
\hline
\end{tabular}

\section{Results}

\section{Survey and Pathogenecity for Powdery and Downy mildew pathogens}

Field surveys were conducted in 3 major grapevine growing districts in Tamil Nadu viz., Coimbatore, Theni and Dindugal during 2011 and observations of the incidence of downy mildew and powdery mildew were recorded and Percent Disease Index (PDI) was worked out.

\subsection{Downy mildew (Plasmopara viticola)}

The results from the surveys showed that the highest infection of downy mildew with PDI 76.92 was recorded in Cumbum of Theni district, followed by Odapatty (75.63), and Theenampalayam (73.26) of Coimbatore. The same scenario was noticed on the incidences of inflorescences and fruits wherein, the Cumbum of Theni recorded (75.15) followed by Odapatty (73.29) and Theenampalayam (70.32) of Coimbatore in inflorescences. In the case of fruits also, Cumbum and Odapatty of Theni district recorded PDIs of 72.32, 71.69 percent, followed by Theenampalayam of Coimbatore (68.15). 
2.2 Efficacy of Azoxystrobin 8.3\%w/w + Mancozeb 68.75\% and other fungicides against the spore germination of P.viticola and $U$.necator

From the results, it was inferred from the data that Azoxystrobin 8.3\%w/w + Mancozeb 68.75\% was found to be more effective than other four fungicides in inhibiting the sporangial germination of P.viticola at 0.36 per cent concentration as it recorded $89.26 \%$ inhibition as compared to 88.90 and 77.39 in $0.30 \%$ and $0.24 \%$ concentrations respectively. Among other fungicides, azoxystrobin was found to show 72.06 percent inhibition followed by mancozeb which recorded $62.54 \%$, whereas the least inhibition of 55.32 was recorded in hexaconazole. The combination of metalaxyl+ mancozeb was found to be more effective when compared to mancozeb alone as it recorded 66.85 per cent reduction as compared to 62.54 per cent in mancozeb. The similar findings were also reported by several workers.

\subsection{Efficacy of Azoxystrobin 8.3\%w/w + Mancozeb 68.75\% and other fungicides against the spore germination of U.necator}

The studies on the effect of fungicides on the conidial germination of U.necator also yielded the same result. The new fungicide, Azoxystrobin $8.3 \%$ + Mancozeb $68.75 \%$ in all three concentrations, was found to be superior in inhibiting the spore germination by recording $90.27 \%, 89.91 \%, 80.70 \%$ respectively in $0.36,0.30$ and $\quad 0.24 \quad$ concentrations. Mancozeb recorded 76.30 per cent inhibition, followed by azoxystrobin (70.94). The least inhibition of 58.73 was recorded in hexaconazole. The combination of metalaxyl+mancozeb was found to be less effective when compared to mancozeb alone, as it recorded 65.88 per cent reduction as compared to 76.30 per cent in mancozeb. The similar findings were also reported by several workers.

\section{Discussion}

Practically no survey reports was available on the incidence of downy mildew disease in different districts of Tamil Nadu and this seems to be the new study. However, In India the disease was first reported by Syndow and Butler, 1912[11] from Pune, Maharashtra. Subsequently the incidence of downy mildew was reported from different places in India. First time Ramakrishnan and Sundaram (1955) [12]reported the occurrence of this disease in Tamil Nadu. Field surveys were conducted indicated that the powdery mildew infection with highest incidence of PDI on leaves, inflorescence and fruits were observed in Cumbum of Theni with records of $65.49,63.56,61.23$ percent respectively. This was followed by Odapatty of Theni $62.38,60.12$, 58.34 respectively on leaves, inflorescence and fruits.

In Coimbatore, the highest incidences were recorded in Theenampalayam with the incidences of 61.56, 60.02 and 57.49 percent respectively on leaves, inflorescences and fruits. In general, it was observed that among the three locations, Dindugal district recorded less incidence of downy mildew and powdery mildew when compared to other districts. Practically no survey report was available on the incidence of powdery mildew in different districts of Tamil Nadu and this seems to be the new study. However reports from other parts of India were reviewed. Sohi (1983)[13] reported that in South India, the loss in yield was reported upto $p$ to 50 per cent due to infection by this disease. Sendhil Vel (2003)[14] studied the in vitro efficacy of azoxystrobin against the spore germination of downy mildew of grapes and found that even at a concentration of $100 \mathrm{ppm}$, it was able to reduce the germination up to 90 percent, with an increasing concentration of the chemical (250, 500, 750 and $1000 \quad \mathrm{ppm})$ complete inhibition of germination. Nithyameenakshi et al. (2006)[15] reported that in vitro study of spore germination revealed that azoxystrobin at $0.05 \%$ arrest the spore propagules of downy mildew, powdery mildew and anthracnose of grapes.

Archana (2009)[16] reported the extent of inhibition of sporangial germination increased with the increase in concentration of fungicides. Among them, Azoxystrobin (23 SC) completely inhibited the sporangial germination of $P$. viticola at $300 \mathrm{ppm}$ onwards. Similarly, Azoxystrobin (23 SC) recorded cent per cent inhibition of conidial germination at a concentration of $250 \mathrm{ppm}$ and above. Azoxystrobin provided cent per cent control of downy mildew in grapes, when applied 1 to 5 days before inoculation and 85 per cent mean reduction of resporulation from diseased tissue, when applied 6 days after inoculation (Wong and Wicox, 2001)[17]. Azoxystrobin inhibited the conidia to germinate and formation of appressoria in black rot (Guiganardia bidwelli) pathogen of grape (Hoffman and Wilcox, 2003)[18].

Ravikumar (1998)[19] reported that penconazole $(0.1 \%)$ difenconazole $(0.1 \%)$, nimbicidin $(0.3 \%)$ and neemark $(0.3 \%)$ were effective against Sphaerotheca pannosa in laboratory conditions using agar plate method. Dhruj et al. (2000)[20] reported that hexaconazole, penconazole and wettable sulphur were found effective against powdery mildew of fenugreek. 


\section{Acknowledgements}

The authors are thankful to M/S United Phosphorus Limited, Mumbai for funding and providing the valuable suggestions during my research period

[1]. Indian Horticulture Database-2011.

\section{References}

[2]. CMI.1988. Distribution Maps of Plant Diseases, Fourth Edition. Common wealth Mycological Institute Publication, London, Map 221.

[3]. Rao, K.C. 1991. Management of grapevine powdery mildew with sterol inhibiting fungicides. Pestology, 15:43-45.

[4]. Ravikumar, M.R. 2007. Bio-efficacy of Ridomil gold 68 WG (Metalaxyl - M + Mancozeb $4+64$ WG) in the management of downy mildew of grape in northern Karnataka caused by Plasmopora viticola (Berk and Curt) Berl. Det. Pestology, $31: 21-23$.

[5]. Bartlett, D.W., John, M., Clough Chris, R., Godfrey,A., Jeremy, R., Godwin, G., Alison, A., Hall., Steve, P. Heaney and Steve J. Maund. 2001. International Research Centre discuss the biology, ecology and resistance management of the strobilurins, especially picoxystrobin, the latest member of the class from Syngenta at Jealott's Hill. Pesticide Outlook, 4: 143-148.

[6]. Berg, G. L. 1988. Farm chemicals handbook. Willoughby, OH: Meister Publishing Co. pp. 45-49.

[7]. Jamadar, M. and Desai, S.A. 1997. Bioefficacy of dimethomorph against downy mildew of grapevine. Adv. Agric. Res . India, 4: 81-85.

[8]. Vimala, R. 2005. Studies on Powdery Mildew of Bhendi Caused by Erysiphe cichoracearum DC) Ph.D. Thesis, Tamil Nadu Agric. Univ., Madurai, India, p. 120.

[9]. CSFT. 1943. Committee on Standardization of Fungicidal Tests. The slide germination method of evaluating protectant fungicide. American Phytopathological Society, New York/ p. 860.

[10]. Varalakshmi, S., Raguchander, T., Kuttalam, S. and Samiyappan, R. 1999. Bioefficacy and persistence of hexaconazole against powdery mildew of grapes. Pestology, 23: 22-26.

[11]. Ramakrishnan, T.S. and Sundaram, N.V. 1955. Grapevine diseases and their control. Madras Agric. J., 42: 109-113.

[12]. Sohi, H.S. 1983. Diseases of tropical and sub tropical fruits and their control. In: Recent Advances in Plant Pathology. (Eds.) Akhtar Husain, Kishan singh, B.P.Singh and V.P.Agni hotri, Print House, Lucknow.pp.73-86.

[13]. Sendhil Vel,V.2003. Evaluation of azoxystrobin 25 SC against downy mildew and powdery mildew of grapevine. Ph.D. Thesis, Tamil Nadu Agric. Univ., Coimbatore, India. 190p.

[14]. Nithyameenakshi, S., Jeyaramraja, P.R. and Manian, S. 2006. Evaluation of Azoxystrobin and Difenoconazole against certain crop diseases. International J. Agric. Res., 1: 420 -431.

[15]. Archana. S. 2009. Studies on the evaluation of azoxystrobin 23 Sc against Downy mildew and powdery mildew of grapevine. M.Sc.(Ag.) Thesis, Tamil Nadu Agric. Univ., Coimbatore, India. 55 p.

[16]. Wong, F.P. and Wilcox, W.F. 2002. Sensitivity to azoxystrobin among isolates of Uncinula necator: Baseline distribution and relationship to myclobutanil sensitivity. Plant Dis., 86: 394-404.

[17]. Hoffman, L.E. and Wilcox, W.F. 2003. Factors influencing the efficacy of myclobutanil and azoxystrobin for control of grape black rot. Plant Dis., 87: 273-281.

[18]. Ravikumar, B.P. 1998. Studies on powdery mildew of rose caused by Sphaerotheca pannosa Var. rosae (Wallr.) Lev. M.Sc. (Agri.) Thesis, University of Agricultural Sciences, Dharwad

[19]. Dhruj, I.V., Akbari, R.R., Khandar and Jadeja, K.B. 2000. Field evaluation of fungicides against powdery mildew of Fenugree.J.Mycolology and Plant Pathology. 30: 98-99.

[20]. Syndow, H. and Butler, E.J. 1912. Fungi India Orientasles pars. Ann. Mycol., 9:372-421. 